\title{
TROVAS
}

\section{(De amor e desamor)}

\author{
ADELAIDE $M$. VILLA
}

Universidade Federal do Paraná

\section{CANTEMOS!}

Cante, amigo ou inimigo,

cantemos todos, em côro,

pois é verdade o que digo:

onde há canto, não há chôro.

\section{AMOR DE MAE \\ Coração de mãe é fonte donde flui tanto amor que, se a vida é sêco monte ela a fez vergel em flor.}

\section{TEIMOSIA}

Como na antiga canção

"Hei de amar-te até morrer", jura o doido coração

se a razão manda esquecer.

\section{POR QUE?}

Por que o tal "ego" da gente que não se mostra a ninguém, não pode viver contente sem suspirar por alguém? 


\section{JURAMENTO}

Foi num momento de dor, que jurei, lavada em pranto, não dar migalha de amor sem receber outro tanto.

\section{PEDIDO}

"Teus olhos quero emprestados", disseste, um dia, a sorrir; "quero ferir-fe c'os dardos que usaste $p$ 'ra me ferir".

\section{QUITAÇÃO}

Perdi o anel que fu me deste, em sinal de bem querer; esqueci o mal que fizeste deixando de me querer.

\section{CASTIGO}

"Quem alguém com ferro fere com ferro será ferido"; por isso aquêle que trai acaba sendo traído.

\section{VIDA MALVADA}

Não há rosa sem espinho nesta vida atribulada, depois de um terno carinho é quase certa a pancada.

\section{- tiquetaque do coração}

O coração que ama bate num compasso irregular; mas se iguala o tiquetaque é que já deixou de amar.

\section{PAIXÃO}

A onda enlaça a rocha erguida num delírio de paixão, depois baixa arrependida com suspeita mansidão. 


\section{DILEMA}

"Ama, sê crédulo e espera"

é o conselho da razão.

"Mas a ausência desespera", diz a voz do coração.

\section{CURIOSIDADE}

Quisera ir a outros mundos para ver se encontro lá, ódios e amôres profundos como os encontro por cá.

\section{INVEJA}

Se o bom riso a gente goza, diz o adágio popular, vem a lágrima invejosa o alegre amigo expulsar.

\section{MISTÉRIO}

Quanto mais a gente pensa que já esqueceu um amor, mais sua terna lembrança a saudade vem impor.

\section{O RELOGIO}

Meu relógio bate as horas num compasso diferente: devagar, se a vir demoras, se aqui estás, ràpidamente.

\section{LIRISMO}

Uma viola, um pinheiro, uma orgia de luar, a cabrocha e o companheiro conjugando o verbo amar.

\section{A CONFISSĀO}

A vida sem ti é deserto onde só vinga a amargura, mas se torna céu aberto se me busca tua ternura. 


\section{PEJO}

Mandou que a rosa falasse com carinho ao seu amor êste a pousou junto à face para esconder seu rubor.

\section{IMPOSSIVEL}

Peça tudo o que quiser e de obtenção possível, mas não peça que o esqueça que é pedir o impossivel.

\section{INCOERENCIA}

Quando falavam no amor, sorria, feliz, descrente; hoje, acredita no amor e chora frequientemente.

\section{OBSESSÃO}

Pensando em ti passo o dia irrequieta a suspirar; chega a noite e esta agonia persiste no meu sonhar.

\section{CANTE!}

Cante, qualquer dia ou hora que a vida é breve demais; cantando, menos se chora, chorando, se sofre mais. 